\title{
A specific subset of SR proteins shuttles continuously between the nucleus and the cytoplasm
}

\author{
Javier F. Cáceres, ${ }^{1,3,4}$ Gavin R. Screaton, ${ }^{2}$ and Adrian R. Krainer ${ }^{1,4}$ \\ ${ }^{1}$ Cold Spring Harbor Laboratory, Cold Spring Harbor, N ew York 11724-2208 USA; ${ }^{2}$ Institute of Molecular M edicine, John \\ Radcliffe Hospital, Headington, Oxford OX3 9DU, UK
}

The SR proteins constitute a large family of nuclear phosphoproteins required for constitutive pre-mRNA splicing. These factors also have global, concentration-dependent effects on altemative splicing regulation and this activity is antagonized by members of the hnRNP A/B family of proteins. We show here that whereas some human SR proteins are confined to the nucleus, three of them-SF2/ASF, SRp20, and 9G8-shuttle rapidly and continuously between the nucleus and the cytoplasm. By swapping the corresponding domains between shuttling and nonshuttling SR proteins, we show that the carboxy-terminal arginine/serine-rich (RS) domain is required for shuttling. This domain, however, is not sufficient to promote shuttling of an unrelated protein reporter, suggesting that stable RNA binding mediated by the RNA-recognition motifs may be required for shuttling. Consistent with such a requirement, a double point-mutation in RRM1 of SF2/ASF that impairs RNA binding prevents the protein from shuttling In addition, we show that phosphorylation of the RS domain affects the shuttling properties of SR proteins. These findings show that different SR proteins have unique intracellular transport properties and suggest that the family members that shuttle may have roles not only in nuclear pre-mRNA splicing but also in mRNA transport, cytoplasmic events, and/or processes that involve communication between the nucleus and the cytoplasm.

[Key Words: Pre-mRN A splicing; SR proteins; nucleocytoplasmic shuttling; heterokaryons; RS domain]

Received July 17, 1997; revised version accepted October 28, 1997.

The SR proteins are closely related, highly conserved RNA-binding proteins that have dual roles in pre-mRN A splicing. They are essential for constitutive splicing and al so regul ate splicing in a concentration-dependent manner by influencing the sel ection of alternative spl icesites (Ge and M anley 1990; Krainer et al. 1990a,b; Zahler et al . 1993; for review, see Fu 1995; Manley and Tacke 1996; Cáceres and Krainer 1997). The activity of SR proteins in regulated splicing is antagonized by members of the hnRNP A/B family of proteins (Mayeda and Krainer 1992; M ayeda et al. 1994) and alterations in the ratio of these antagonistic factors cause drastic changes in splice-site selection both in vitro and in vivo (Mayeda and Krainer 1992; Cáceres et al. 1994; Yang et al. 1994). The relative abundance of each SR protein and the molar ratio of each SR protein to hnRN P A 1 or to other antagonists may therefore determine the patterns of al ternative splicing of many genes expressed in specific cell types. Tissue-specific variations in the total and relative amounts of SR proteins or mRN As have been described

\footnotetext{
${ }^{3}$ Present address: MRC Human Genetics Unit, Westem General Hospital, Edinburgh EH4 2XU, UK.

${ }^{4}$ Corresponding authors.

E-MAIL krainer@cshl.org, FAX (516)-367-8453. E-MAIL Javier.Caceres@ hgu.mrc.ac.uk; FAX 441313432620.
}

(for review, see Cáceres and Krainer 1997) and in addition, the molar rati o of SF2/ ASF to hnRN PA 1 varies over a wide range in different rat tissues (A. Hanamura, J.F. Cáceres, A. Mayeda, and A.R. Krainer, in prep.).

The SR proteins are nuclear phosphoproteins that are concentrated, together with most other splicing factors, in nuclear subregions termed speckles. The speckle domain seen by immunofluorescence corresponds to interchromatin granule clusters and perichromatin fibrils at the electron microscope level (for review, see Spector 1993). The nuclear organization of splicing factors is dynamic, and it has been proposed that SR proteins and other splicing factors are recruited from the interchromatin granule clusters, which are believed to be sites of storage or assembly, to the sites of active transcription (Jiménez-García and Spector 1993; M attaj 1994; Huang and Spector 1996; Misteli et al. 1997).

A nother nuclear protein involved in splicing, hnRN P A1, although localized primarily in the nucleoplasm, shuttles continuously between the nucleus and the cytoplasm (Piñol-Roma and Dreyfuss 1991, 1992; Weighardt et al. 1995). Among the superfamily of hnRNP proteins, it was found that not only hnRNP A1, but also A2, D, E, I, and $K$ shuttle continuously between the nucleus and the cytopl asm, whereas hnRN P C1, C2, 
and $\mathrm{U}$ are confined to the nucleus (Piñol-Roma and Dreyfuss 1992, 1993; Michael et al. 1995a). Recently, a nuclear retention signal in hnRNP C1 was identified ( $N$ akielny and Dreyfuss 1996). hnRNP Al is exported out of the nucleus, probably bound to mRNA, remains associated with poly $(A)^{+}$RN A in the cytoplasm, and is reimported into the nucleus after dissociating from the RNA. The fact that hnRNPAl is bound to mRNA in both cellular compartments suggested that shuttling hnRNP proteins may be invol ved in the nucleocytoplasmic trafficking of mRNA (Piñol-Roma and Dreyfuss 1992). The nuclear reimport of hnRN P A1 depends on ongoing transcription and is not mediated by a canonical nuclear localization signal. A carboxy-terminal sequence in hnRNP A1, termed M9, which is involved in both nuclear import and export, has been identified (Michael et al. 1995b; Siomi and Dreyfuss 1995; Weighardt et al. 1995). It has been shown that M 9-mediated nuclear import occurs by a novel pathway, which is independent of the classical importin-mediated N LS pathway, and involves an M 9-interacting protein, transportin (Pollard et al. 1996). More recently, a different motif, termed KNS, has been shown to be responsi ble for bi directional transport across the nuclear envel ope by the shuttling hnRN P K protein (Michael et al. 1997).

In addition to certain hnRNP proteins, several other cellular or viral proteins are known to shuttle between the nucleus and the cytoplasm (for review, see Nigg 1997). These include nucleolar proteins, such as N O38, nucleolin, and Nopp140 (Borer et al. 1989; Meier and Bl obel 1992), steroid hormone receptors, such as the progesterone receptor (Guiochon-M antel et al. 1991), the U 1 snRN P-specific polypeptide U1A (Kambach and Mattaj 1992), heat shock-related proteins ( $M$ andell and Fel dherr 1990), the HIV-1 Rev protein (Meyer and Malim 1994), and the Saccharomyces cerevisiae protein N pl3p (Flach et al. 1994; Lee et al. 1996). Although the precise functi ons of nucl eocytopl asmic shuttling are not understood, this process may reflect the role of shuttling proteins as carriers for the delivery of protein or RNA molecules to the nucl eus and cytoplasm. A Iternatively, these proteins may have evolved to perform different functions in the nucleus and in the cytopl asm.

Electron microscopy studies of specific, giant premRN P particles-the Bal biani ring granul etranscripts in the salivary glands of the dipteran Chironomus tentans-showed that the substrate for mRNA export is an RNP particle (for review, see Mehlin and Daneholt 1993). A mong the proteins bound to this RN P particle, three distinct classes have been described, represented by (1) a protein related to human hnRN P A 1, which exits the nucleus in association with the RN P particle and is found in the cytoplasm bound to polysomes (Visa et al. 1996a); (2) CBP20, a cap-binding protein that travels across the nuclear membrane in association with the RN P particle but is released from the RN A immediately after crossing the nuclear membrane (Visa et al. 1996b); and (3) an SR protein that is visualized in the nucleus as an RN P but never leaves the nucleus (Alzhanova-Ericsson et al. 1996).
We determined recently the signals within different SR proteins responsible for nuclear import and localization to the nuclear speckles (Cáceres et al. 1997). In the present study we focused on the dynamics of SR protein intracel lul ar localization. We found that al though the SR proteins accumulate in the nucleus at steady state, a subset of them shuttle continuously between the nucleus and the cytoplasm. We used techniques applied previously to the study of other shuttling proteins, such as hnRNP A 1, as a positive control. This new activity of a distinct subset of SR proteins suggests that shuttling and nonshuttling SR proteins have at least some different functions and implicates the former in mRNA transport or cytoplasmic functions.

\section{Results}

Analysis of SR protein shuttling by transcription inhibition

First, we analyzed two SR proteins, SF2/ASF and SC 35 , for which specific monocl onal antibodies are available, allowing the detection of the endogenous proteins. The SC 35 antibody recognizes a phosphoepitope (Fu and $\mathrm{Ma}$ niatis 1990), whereas the SF2/ASF recognizes both phosphorylated and unphosphorylated forms of the protein (A. Hanamura, J.F. Cáceres, A. M ayeda, and A.R. Krainer, in prep.). Many shuttling proteins accumulate in the cytoplasm when cells are incubated with inhibitors of RNA polymerase II transcription (Dreyfuss et al. 1993) and this property has been commonly used to identify new shuttling proteins. This effect relies on the fact that nuclear reimport requires ongoing transcription, for reasons that are not fully understood. Addition of $5 \mu \mathrm{g} / \mathrm{ml}$ actinomycin D in the presence of cycloheximide for $3 \mathrm{hr}$ resulted in the accumulation of SF2/ASF in the cytoplasm, whereas SC35 remained exclusively in the nucleus (Fig. 1A). Similar results were observed with another inhibitor of transcription, 5,6-dichloro-1- $\beta$-D-ribofuranosylbenzimidazole (DRB) (Zandomeni et al. 1986). This reversible inhibitor also resulted in rounding up of the speckles, as described previously (Spector et al. 1983). Incubation of HeLa cells with cycloheximide alone had no effect (data not shown). These results suggest that SF2/ASF is a shuttling protein. SC35 did not appear to shuttle by this assay, although the apparent absence of the protein in the cytoplasm could in principle reflect the loss of the phosphoepitope.

To extend these findings to other SR proteins, we used transient transfection of HeLa cells with T7 gene 10 epitope-tagged SR protein CDNAs, as antibodies specific to each SR protein are not available in most cases. The localization of the transiently expressed proteins was determined by indirect immunofluorescence in the presence or absence of actinomycin D. All epitope-tagged SR proteins local ized properly to the nucleus, concentrating in speckles, as described previously (Cáceres et al. 1997) (Fig. 1B). We showed previously that T7 gene 10-tagged SR proteins are active in an in vivo al ternative splicing assay (Cáceres et al. 1997). Incubation of the transfected 


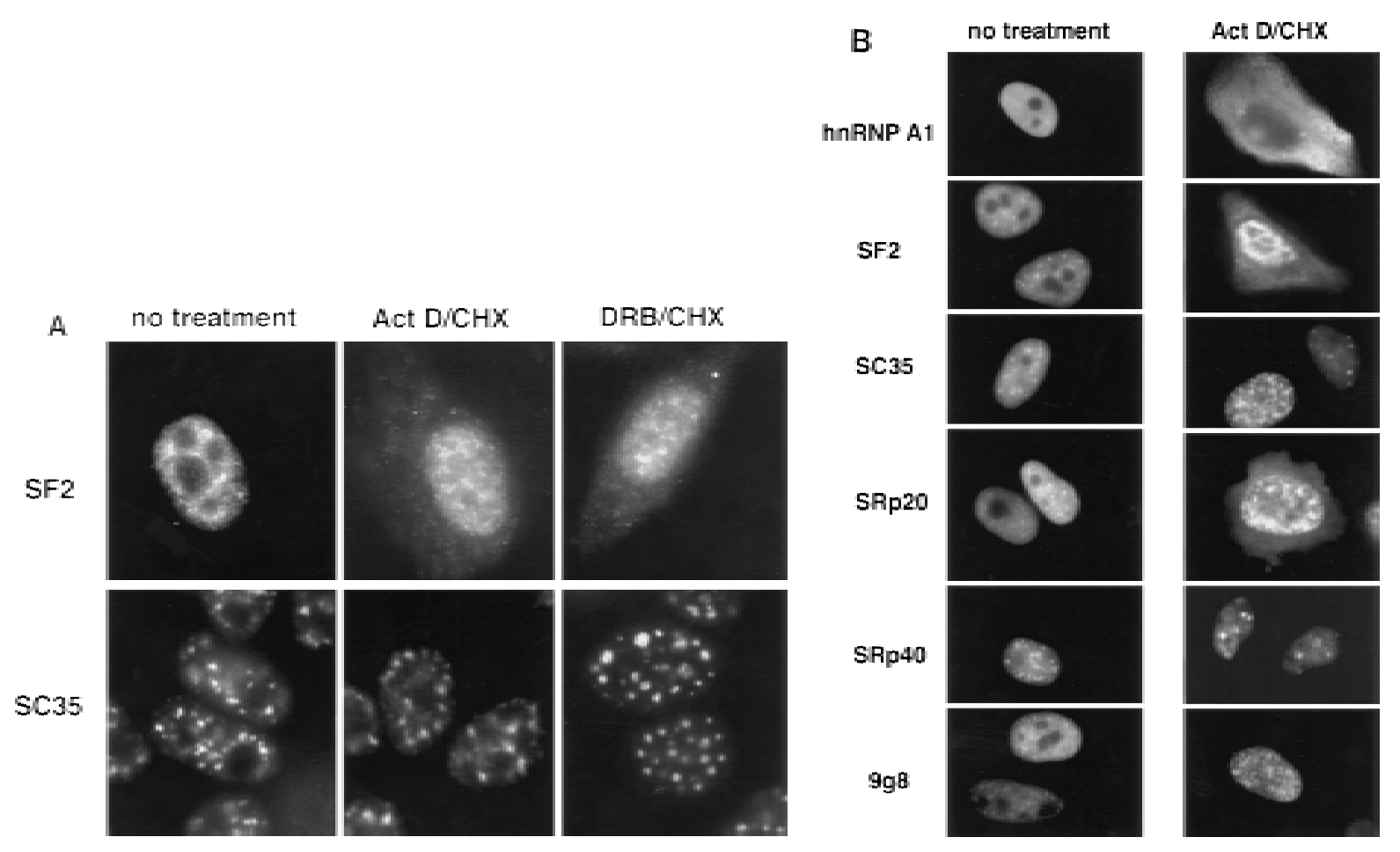

Figure 1. Effect of transcription inhibition on subcellular localization of SR proteins. (A) Endogenous SF2/ASF and SC 35. HeLa cells were incubated al one (left panels), or in the presence of actinomycin D plus cycloheximide (middle panels), or of DRB plus cycloheximide (right panels) for $3 \mathrm{hr}$. The cells were fixed and the localization of SF2/ASF and of SC 35 was determined by indirect immunofluorescence with an anti-SF2/ASF monoclonal antibody (top panels) or an SC 35 monoclonal antibody (bottom panels). Cycloheximide al one had no effect, and was included together with the transcription inhibitors to prevent further protein synthesis from pre-existing mRN A. (B) Transiently expressed SR proteins. HeLa cells were transfected with expression plasmids encoding the indicated T7 epitope-tagged SR proteins, or hnRNP Al as a control. At $24 \mathrm{hr}$ post-transfection, the cells were incubated with actinomycin D plus cycloheximide (right panels) or mock treated (left panels) for $3 \mathrm{hr}$ and subsequently fixed. The local ization of the tagged proteins was determined by indirect immunofluorescence with anti-T 7 monoclonal antibody and FITC-conjugated secondary antibody.

cells with actinomycin $\mathrm{D}$ and cycloheximide resulted in the cytoplasmic accumulation of SF2/ASF, and also of SRp20. hnRNP A1 also localized to the cytoplasm, as described previously (Piñol-Roma and Dreyfuss 1992). This experiment strongly suggests that SF2/ASF and SR 20 are shuttling proteins, whereas SC 35, SRp40, and 9G8 are confined to the nucleus under the same conditions. The lack of shuttling by transiently expressed SC 35, as detected through the epitope tag, confirms that SC 35 remains nuclear under these conditions, and therefore the above observation (Fig. 1A) was not an artifact of detection of the endogenous protein through a phosphoepitope. These experiments al one do not rule out the possibility that SC 35, SRp40, or 9G8 also shuttle, but that their reimport is independent of transcription.

\section{Shuttling of SR proteins in interspecies heterokaryons}

To confirm these initial observations with a different assay that does not rely on transcription inhibition, we used transient transfection in conjunction with interspecies heterokaryons (Michael et al. 1995b). A description of the experimental approach is presented in Figure 2A. In essence, Hela cells were transfected with epitope- tagged SR protein CDNAs and then fused to mouse NIH 3T 3 cells to form heterokaryons. Before fusion, the cells were treated with cycloheximide, so that no further protein synthesis takes place in the heterokaryons. At $2 \mathrm{hr}$ postfusion, the cells were fixed and stained to examine the distribution of the tagged proteins by immunofluorescence microscopy with a monoclonal antibody directed agai nst the epitope tag. To distinguish the human and mouse nuclei, the cells were stained with the dye Hoechst 33258, which gives a characteristic staining of intranuclear bodies in the mouse nuclei. Detection of the tagged protein-expressed originally in the human cells-within the mouse nuclei in the heterokaryons is indicative of shuttling (and therefore of nuclear export). In agreement with the transcription inhibition experiments, SF2/ASF and SRp20, as well as the hnRNP A 1 control, were detected in the mouse nuclei, demonstrating that these proteins were exported from the human nuclei (Fig. 2B). In addition, we observed that the SR protein 9G8, whose cellular distribution is not affected by transcription inhibition, does shuttle in the heterokaryon assay. Previous studies of shuttling by hnRNP proteins showed that some of them, such as hnRNP K, are not affected by transcription inhibition (Piñol-Roma 


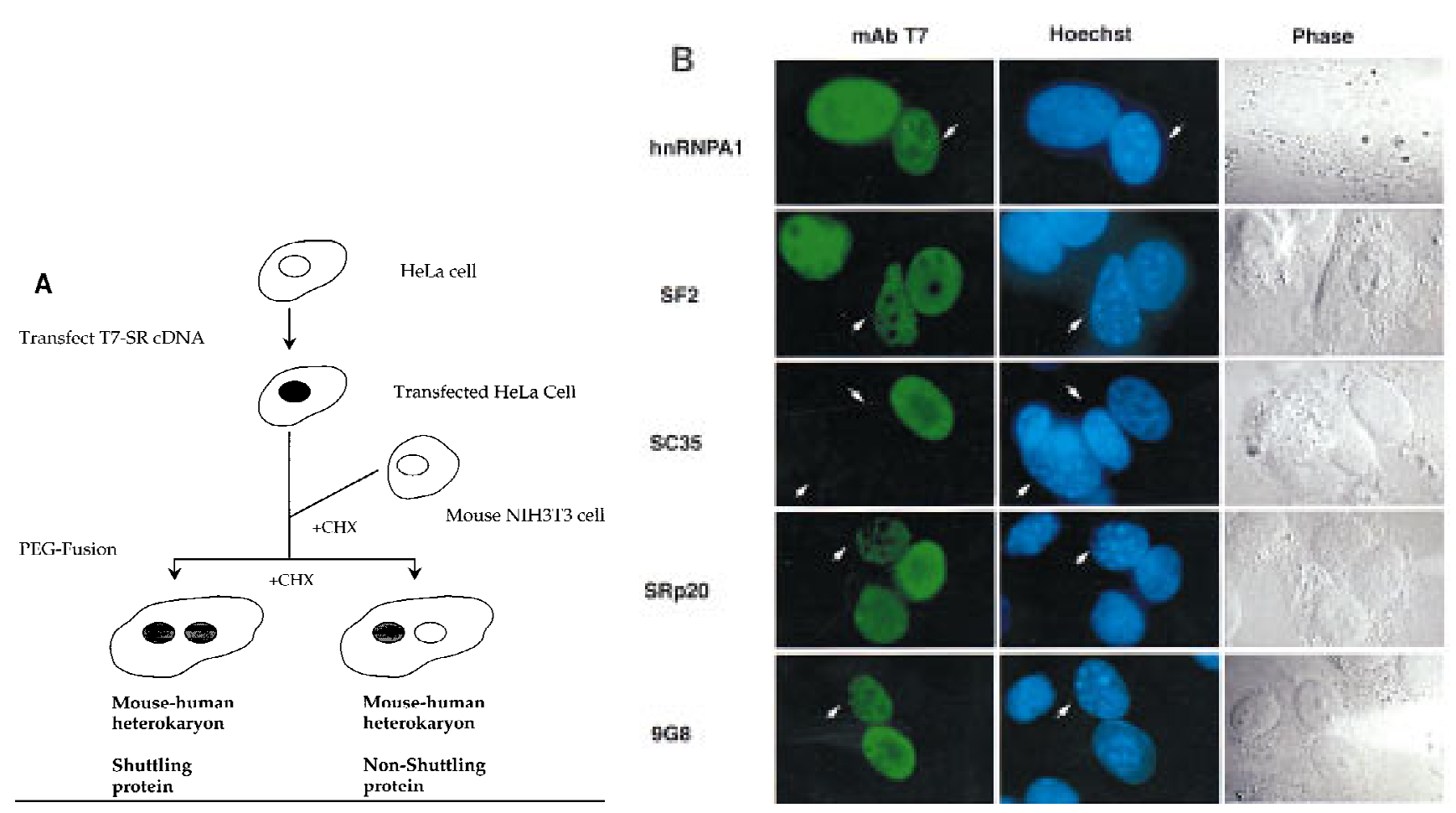

Figure 2. Analysis of nucleocytoplasmic shuttling of SR proteins by transient expression in interspecies heterokaryons. (A) Diagram of the experimental approach. The shaded nuclei indicate localization of the transiently expressed human SR protein. Cycloheximide (CHX) was added before fusion to prevent further protein synthesis from the human mRN A in the heterokaryons. (B) Detection of the transiently expressed SR proteins in interspecies heterokaryons. HeLa cells were transfected with expression plasmids encoding the indicated T7 epitope-tagged proteins, or hnRNP A1 as a control. At $24 \mathrm{hr}$ post-transfection, the HeLa cells were treated with cycloheximide and subsequently fused with mouse N IH 3T 3 cells in the presence of polyethylene glycol to form heterokaryons. The cells were incubated further for $2 \mathrm{hr}$ in the presence of cycloheximide, followed by fixation. The localization of the expressed proteins was determined by indirect immunofluorescence with anti-T7 monoclonal antibody and FITC-conjugated secondary antibody (left panels). The cells were simultaneously incubated with Hoechst 33258 for differential staining of human and mouse nuclei within heterokaryons (middle panels). The arrows indicate the mouse nuclei within human-mouse heterokaryons. Phase-contrast images of the same heterokaryons are shown (right panels).

and Dreyfuss 1993; Michael et al. 1997). In contrast, SC 35 (Fig. 2B) and SRp40 (data not shown) were only detected in the HeLa cell nuclei and therefore appear to be confined to the nucleus and not shuttle.

\section{Domain requirements for shuttling by SR proteins}

To investigate the sequence requirements for nucleocytoplasmic shuttling of SR proteins, we constructed several chimeric proteins by swapping individual domains between a shuttling SR protein, SF2/ASF, and two nonshuttling ones, SRp40 and SC 35. SF2/ASF and SRp40 have identical domain structures, consisting of two RNA-recognition motifs (RRMs) and a carboxy-terminal arginine/serine-rich (RS) domain, whereas SC 35 is simiIar but lacks the second RRM. We analyzed the distribution of the chimeric proteins using both the transcription inhibition and the heterokaryon assays. The results obtained with several chimeras between SF2/ASF and SRp40 indicate that the RS domain of SF2/ASF is essential for the shuttling process (Fig. 3A). Therefore, replacement of the RS domain of SF2/ASF with the corresponding domain from SRp40 resulted in a chimeric protein that was confined to the nucleus $\left(\mathrm{I}_{\mathrm{SF} 2} \mathrm{Il}_{\mathrm{SF} 2} \mathrm{RS}_{40}\right)$. The reciprocal chimera, consisting of both RRM s from SRp40 and the RS domain from SF2/ASF, displayed nuclear and cytoplasmic localization even in the absence of actinomycin D (data not shown). This property may reflect a reduced rate of nuclear import or an increased rate of export, and is therefore ambiguous with respect to shuttling. The identity of the second RRM does not influence shuttling, as a chimera in which the second RRM of SF2/ASF is replaced by that of SRp40 $\left(I_{S F 2} I_{40} R_{S F 2}\right)$ has the same properties as wild-type SF2/ASF (Fig. 3A). Like wise, chimeras that contain the second RRM from SF2/ ASF but the RS domain from SRp40 $\left(\mathrm{I}_{\mathrm{SF} 2} \mathrm{II}_{\mathrm{SF} 2} \mathrm{RS}_{40}\right.$ and $\mathrm{I}_{40} \mathrm{II}_{\mathrm{SF} 2} \mathrm{RS}_{40}$ ) behave like SRp40, that is, they do not shuttle (Fig. 3A). Similarly, the identity of the first RRM does not appear to influence shuttling, as chimeras that include the first RRM from SF2/ASF and the RS domain from SRp40 ( $I_{S F 2} I_{S F 2} R_{40}$ and $\left.I_{S F 2} I_{40} R_{40}\right)$ behave like SRp40 and do not shuttle (Fig. 3A).

The importance of the RS domain of SF2/ASF as a shuttling signal was demonstrated further by replacing the RS domain of another nonshuttling SR protein, SC 35, by that of SF2/ASF (Fig. 3B). This single domain 


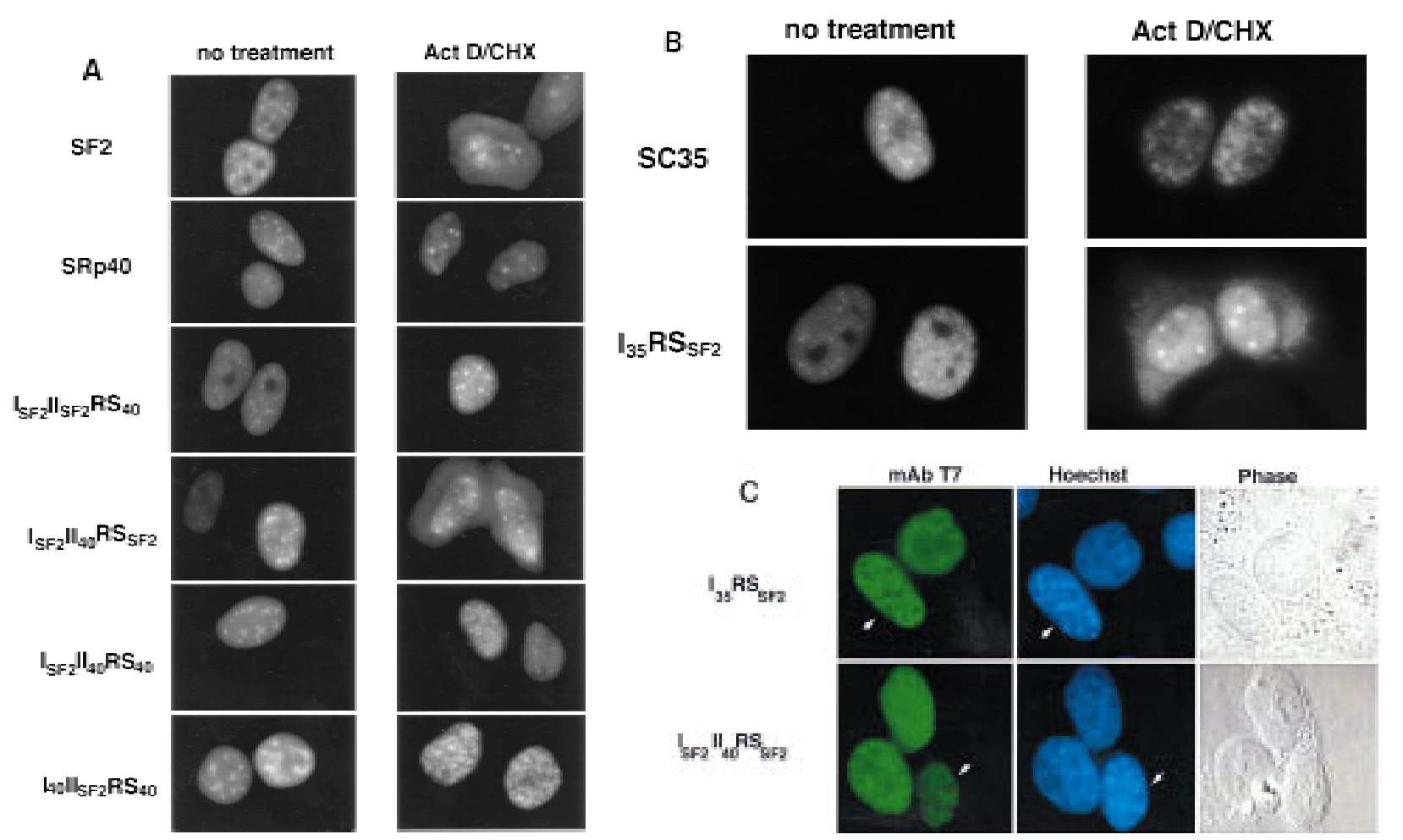

Figure 3. Domain requirements for SR protein shuttling. (A) Analysis of shuttling of SF2/ASF-SRp40 chimeras by transient expression and transcription inhibition. HeLa cells transfected with epitope-tagged constructs and either mock treated (left panels), or treated with actinomycin D and cycloheximide (right panels), were analyzed as in Fig. 1B. SF2/ASF (top row) and SRp40 (second row) are composed of two RRMs and a carboxy-terminal RS domain. The names of the chimeras (bottom four rows) denote the origin of each domain, with RRM 1 and RRM 2 indicated by roman numerals and the subscript indicating whether the domain derives from SF2/ASF or from SRp40. (B) Shuttling by a chimera with the RRM of SC 35 and the RS domain of SF2/ASF. Cells were transfected, treated, and analyzed as in A, using either epitope-tagged SC 35 (top row) or a construct consisting of the single RRM from SC 35 (denoted by $\mathrm{I}_{35}$ ) and the RS domain from SF2/ASF (denoted by RS $_{\mathrm{SF} 2}$ ) replacing the SC 35 carboxy-terminal RS domain. (C) Analysis of shuttling of SR protein chimeras by the heterokaryon assay. SR protein chimeras were transiently expressed in HeLa cells, which were then treated with cycloheximide and fused to N IH 3 T 3 cells. The localization of the epitope-tagged proteins in the heterokaryons was analyzed as in Fig. 2B. The chimeras are named as in A and B, and the arrows indicate the mouse nuclei in the human-mouse heterokaryons. The same heterokaryons were analyzed for localization of the epitope-tagged proteins (left panels), staining with Hoechst 33258 (middle panels), and by phase-contrast (right panels).

swap was sufficient to convert a protein restricted to the nucleus (SC 35) into a protein able to shuttle into and out of the nucleus $\left(\mathrm{I}_{35} \mathrm{RS}_{\mathrm{SF} 2}\right)$. As before, the identity of the RRM did not influence the shuttling properties, and moreover, a second RRM proved dispensable for shuttling, as the RRM of SC 35, which corresponds to the first RRM of SF2/ASF or SRp40 (Birney et al. 1993), could function as the sole RRM in the context of either a nonshuttling protein (SC 35) or a shuttling protein $\left(\mathrm{I}_{35} \mathrm{RS}_{\mathrm{SF}_{2}}\right)$. All of the chimeric proteins were also analyzed by the heterokaryon assay, and results consistent with the transcriptional inhibition assay were obtained (Fig. 3C; data not shown). The role of the RS domain in shuttling $\left(I_{35} R_{S_{F 2}}\right)$ and the lack of effect of RRM2 (I $\left.I_{S_{F} 2} I_{40} R_{S F 2}\right)$ were confirmed (Fig. 3C) as well as the absence of shuttling signals in the RS domain of SRp40 $\left(\mathrm{I}_{\mathrm{SF} 2} \mathrm{II}_{\mathrm{SF}_{2}} \mathrm{RS}_{40}\right.$; data not shown).

To test directly whether the RS domain of a shuttling SR protein is sufficient to promote nuclear export, we fused the RS domain of SF2/ASF, or that of SRp20, to an unrelated protein reporter that does not shuttle, the nucleoplasmin core domain (N PC) (Dingwall et al. 1982, 1987). The distribution of the resulting chimeric proteins was analyzed using both the transcription inhibition and the heterokaryon assays. Although N Pc by itself localizes in the cytoplasm, attributable to the missing bipartite nuclear localization signal of nucleoplasmin, when it is microinjected into the nucleus it does not cross the nuclear envel ope into the cytopl asm (Dingwal I et al . 1982, 1988; Laskey and Dingwall 1993). In addition, when fused to the RS domain of either SF2/ASF or SRp20, which provide a nuclear localization signal, the chimeric proteins accumulate in the nucleus (Cáceres et al. 1997). On inhibition of transcription or in the heterokaryon assay, neither the SF2/ASF RS domain nor the SRp20 RS domain was sufficient to promote the nuclear export of the nucleoplasmin reporter (Fig. 4; data not shown). This finding contrasts with the results obtained with another shuttling protein, hnRNP A 1, in which the M9 export signal is sufficient to promote the nuclear 
Figure 4. The RS domain of shuttling SR proteins is not sufficient for shuttling. Interspecies heterokaryon analysis of transiently expressed fusions of the nucleoplasmin core domain reporter (N PC) and the RS domain of SF2/ASF or SRp20. HeLa cells were transfected with plasmids encoding the indicated epitope-tagged proteins, fused to mouse cells, and the heterokaryons were analyzed as in Fig. 2B.

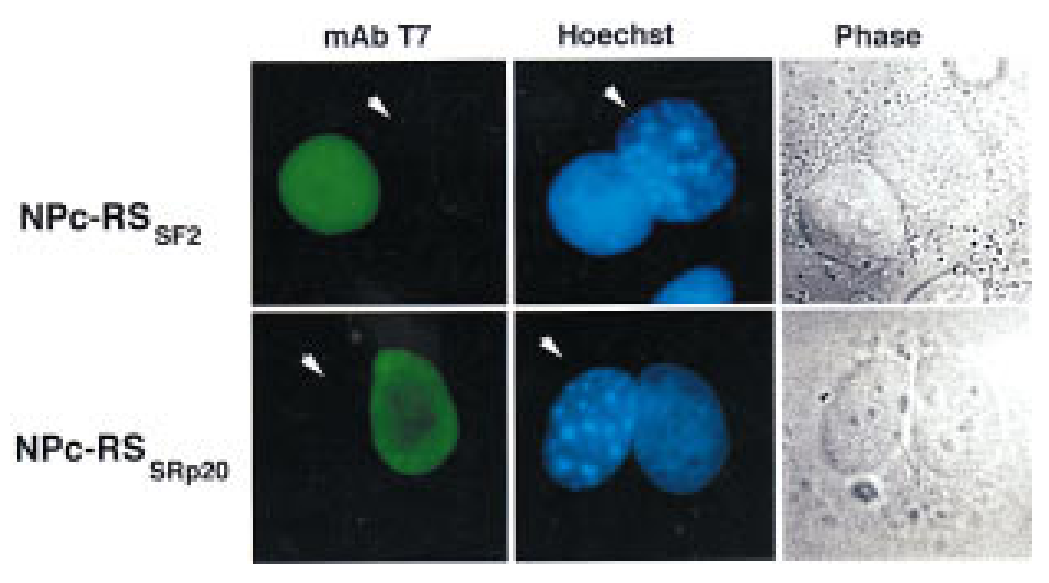

export of the same reporter (Michael et al. 1995b). One possible explanation for the failure of N Pc-RS chimeras to shuttle is that the RS domain is necessary but not sufficient for shuttling, and other signals are required to promote nuclear export. For example, RNA binding mediated by the RRMs may also be required for nuclear export of shuttling SR proteins.

To address the possible involvement of RNA binding in shuttling of SR proteins, we analyzed a mutant of SF2/ASF, in which two conserved phenylalanines in RRM 1, which are thought to stack with single-stranded RNA bases, have been mutated. This previously described mutant has reduced affinity for RN A and is inactive as a general splicing factor in vitro (Cáceres and Krainer 1993). The localization of this transiently expressed protein (SF2 FF-DD) was determined by indirect immunofluorescence in the presence or absence of actinomycin D. Incubation of the transfected cells with actinomycin D and cycloheximide did not alter the cellular localization of the mutant protein, which remained nuclear (Fig. 5, top panels, cf. no treatment with Act $\mathrm{D} / \mathrm{CHX}$ ). This experiment strongly suggests that RNA binding is required for nucleocytopl asmic shuttling.

To address whether particular RRM s must be present, we analyzed another chimera consi sting of both RRM s of hnRNP A 1 fused to the RS domain of SF2/ASF (M ayeda et al . 1994). hnRNP A 1 is al so a shuttling protein, but the signal for shuttling has been mapped to a region separate from the RRM s (Michael et al. 1995b; Weighardt et al. 1995). On incubation with actinomycin D, the A1-RS chimeric protein displayed nuclear and cytoplasmic localization, which is indicative of shuttling (Fig. 5, bottom panels). This result demonstrates that the RS domain of a shuttling SR protein is able to function in the context of unrelated RRMs.

The rapid kinetics of the shuttling of SR proteins suggested that it is an active process. To determine whether shuttling of SR proteins is an active or a diffusion-based process, we measured the effect of temperature on nuclear export of transfected SF2/ASF. On incubation of cells transfected with SF2/ASF CDNA in the presence of the transcriptional inhibitor DRB, cytoplasmic accumuIation of the transiently expressed protein was only evi- dent when theincubation was performed at $37^{\circ} \mathrm{C}$ but not at $4^{\circ} \mathrm{C}$, suggesting that the export leg of the SF2/ASF shuttling pathway is an active process (data not shown). $\mathrm{N}$ ext, DRB was removed from cells that had been incubated at $37^{\circ} \mathrm{C}$, and the cells were placed at either $37^{\circ} \mathrm{C}$ or $4^{\circ} \mathrm{C}$. N uclear localization was observed at $37^{\circ} \mathrm{C}$ but not at $4^{\circ} \mathrm{C}$, indicating that nuclear import is also an active process (data not shown). It has been shown that the nuclear import of classical nuclear localization signal (NLS)-bearing proteins (Breeuwer and Goldfarb 1990), as well as of hnRN P A 1 (M ichael et al . 1995b), is blocked at low temperature. Cells transfected with epitope-tagged SF2/ASF were al so incubated with cycloheximide for 3 $\mathrm{hr}$ and then incubated further at $37^{\circ} \mathrm{C}$ or shifted to $4^{\circ} \mathrm{C}$. Because nuclear import of proteins is inhibited at $4^{\circ} \mathrm{C}$, any export of SF2/ASF would result in cytoplasmic accumulation. No difference was observed in the distributi on of SF2/ASF incubated at these temperatures, further suggesting that nuclear export is an active process (data not shown).

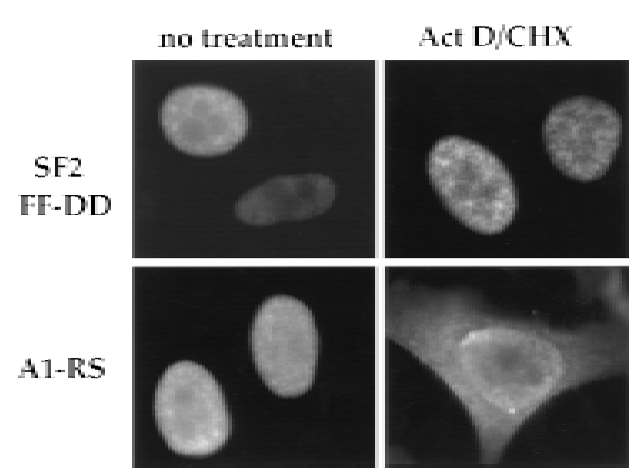

Figure 5. RNA binding is required for shuttling. HeLa cells were transfected with expression plasmids encoding the indicated T 7 epitope-tagged SR proteins. At $24 \mathrm{hr}$ post-transfection, the cells were incubated with actinomycin D plus cycloheximide (right panels) or mock treated (left panels) for $3 \mathrm{hr}$ and subsequently fixed. The localization of the tagged proteins was determined by indirect immunofluorescence with anti-T7 monoclonal antibody and FITC-conjugated secondary antibody. 
Effect of RS domain phosphorylation on SR protein shuttling

Several protein kinases that phosphorylate SR proteins have been described (for review, seeFu 1995). Addition of the SRPK 1 kinase to permeabilized cells or overexpression of the Clk/Sty kinase results in a diffuse distribution of SR proteins, as detected with antibodies that recognize phosphoepitopes in multiple SR proteins. Therefore, it has been suggested that hyperphosphorylation of the RS domains may control the subnucl ear distribution of SR proteins in interphase cells and the reorganization of the speckle domains during mitosis (Gui et al. 1994; Colwill et al. 1996; Misteli and Spector 1996). We analyzed the effect of overexpressing an SR kinase, CIk/Sty, on the subcellular local ization of SF2/ASF and SC 35. As shown in Figure 6A, when we analyzed transiently expressed epitope-tagged SF2/ASF and SC 35, we observed that in both cases, expression of a myc-tagged Clk/Sty kinase caused a reorganization of the speckled pattern, as described previously (C olwill et al. 1996). In addition, we observed that SF2/ASF now accumulated in the cytoplasm, whereas SC 35 remained in the nucleus. Similar results were observed when we analyzed the distribution of SF2/ASF and SC 35 endogenous proteins in cells expressing the Clk/Sty kinase (data not shown), whereas expression of a mutant form of the kinase, Clk/Sty ${ }^{\mathrm{K} 190 \mathrm{R}}$ (Duncan et al. 1995) had no effect on the distribution of SR proteins in the majority of transfected cells (Fig. 6B). In a small proportion of cells transfected with the mutant Clk/Sty kinase, however, cotransfected SF2/ASF was also found in the cytoplasm (data not shown). This limited, but detectable, effect by the catalytically inactive kinase may reflect binding to the substrate without subsequent phosphorylation, and/or an indirect effect by the RS domain of Clk/Sty, particularly in cells where the mutant kinase is expressed at high levels. Clk/Sty is predominantly nuclear, but the presence of an RS domain at its amino terminus suggests that it too may shuttle, although this remains to be determined. N evertheless, the much greater effect on SF2/ASF cytoplasmic accumulation observed by coexpression with the catalytically active kinase suggests that the nuclear reorganization caused by hyperphosphorylation of the RS domains increases the fraction of a shuttling SR protein available for export. Alternatively, phosphorylation by CIk/Sty may inhibit the reimport of shuttling SR proteins.

\section{Discussion}

We used two different assays to show that certain SR proteins are not confined to the nucleus, but rather shuttle continuously between the nucleus and the cytoplasm. Most shuttling proteins are predominantly nuclear at steady state (for review, see N igg 1997). The lack of cytoplasmic staining can be explained by the speed of the bidirectional shuttling process, which is such that the shuttling proteins are present in the cytoplasm only transiently. The short residence time of many shuttling proteins in the cytoplasm makes it difficult to identify them as shuttling proteins; however, a useful assay has been the inhibition of nuclear reimport, which in many cases depends on ongoing transcription (Piñol-Roma and Dreyfuss 1991). This transcription inhibition assay provided the first indication that two out of five SR proteins tested, SF2/ASF and SRp20, are shuttling proteins, as they were trapped in the cytoplasm of HeLa cells treated with actinomycin D or DRB. The properties of SR proteins were anal yzed further by means of a transient interspecies heterokaryon assay (Michael et al. 1995b). In this approach, the mouse nuclei act as a trap for any human nuclear protein that appears, however transiently, in the cytoplasm of the heterokaryon. This analysis confirmed that SF2/ASF and SRp20 are
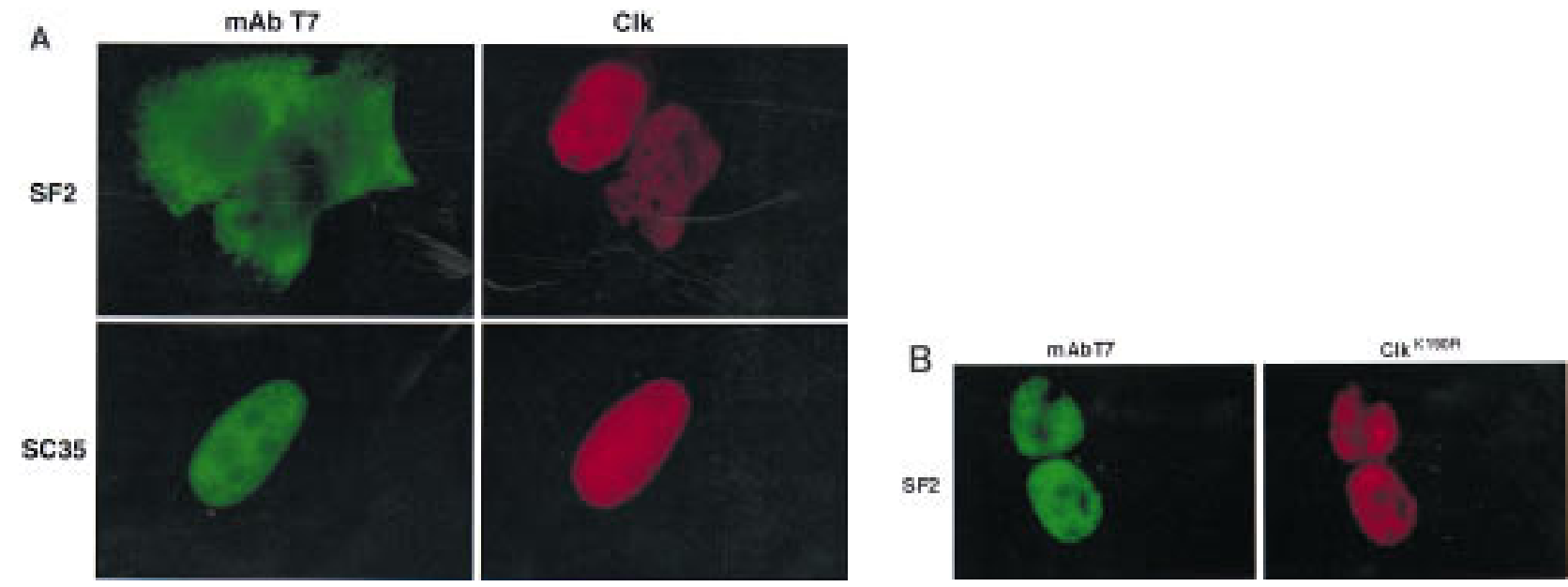

Figure 6. Effect of expression of the CIk/Sty kinase on SF2/ASF shuttling. (A) HeLa cells were cotransfected with plasmids encoding either T7-tagged SF2/ASF (top panels) or SC 35 (bottom panels), together with another plasmid expressing a myc-tagged Clk/Sty kinase. The localization of the transiently expressed SR proteins was determined by indirect immunofluorescence with anti-T 7 monoclonal antibody and FITC-conjugated secondary antibody (left panels), and that of CIk/Sty with a rabbit polyclonal anti-myc antibody and Texas-Red conjugated secondary antibody (right panels). (B) Same as in A, except that a mutant Clk/Sty kinase, Clk/Sty ${ }^{\mathrm{K} 190 \mathrm{R}}$, was cotransfected with T 7-tagged SF2/ASF. 
shuttling proteins, and that SC 35 and SRp40 are not. In addition, this assay revealed that $9 \mathrm{G} 8$ is also a shuttling protein, whose nuclear reimport, unlike that of SF2/ASF and SRp20, does not require ongoing transcription.

\section{Shuttling mechanisms}

The shuttling of SR proteins between the nucleus and the cytoplasm is a rapid process. In the transient transfection interspecies heterokaryon assays, an equilibrium distribution was reached quickly, such that the mouse and human nuclei gave comparable fluorescence intensities in most cases, by 2 hr of incubation after fusion. In contrast, previous studies showed, for example, that shuttling of the nucleolar protein nucleolin occurs much more slowly and did not reach equilibrium until $72 \mathrm{hr}$ (Borer et al. 1989).

Specific nuclear export signals (NES) have been identified in several shuttling proteins, such as hnRN P A 1, a heat-stable inhibitor peptide (PKI) of protein kinase $A$, and the viral protein HIV-1 Rev (for review, see Moore 1996). In the case of hnRNP A1, the M9 sequence is responsible for both nuclear localization and for nucl ear export (Michael et al. 1995b; Siomi and Dreyfuss 1995; Weighardt et al. 1995). In other instances, it appears that the shuttling process does not depend on positive signals that determine nuclear export. For example, the nuclear export of nucleolin does not require positively acting NESs, but instead is determined by structural domains involved in nucleolar retention (Schmidt-Zachmann et al. 1993). In the case of another shuttling protein, the $U 1$ snRN P-specific polypeptide U IA, which binds to stemIoop II of U1 snRNA, the subcellular distribution depends on the availability of binding sites for the protein in each cellular compartment (Kambach and Mattaj 1992).

The fact that hnRN P A 1 recycles between the nucl eus and the cytoplasm and is bound to poly $(A)^{+}$RNA in both compartments suggested strongly that it is exported out of the nucleus bound to mRNA (Piñol-Roma and Dreyfuss 1992). Immunoelectron microscopy anal ysis of Balbiani ring transcripts in Chironomus tentans confirmed that mRN A is exported as an RN P particle; hrp36, which is rel ated to mammal ian hnRNP A 1, and another protein homologous to mammalian CBP20, were both identified as components of exportable RN Ps in this system (Visa et al. 1996a,b; Daneholt 1997). It is possible that the nuclear export signals present in proteins bound to nuclear mRN A act as the driving force for mRNA export, or alternatively, that these NESs facilitate export of mRNA, but additional factors are required. In this regard, a stimulatory role for the cap structure in the export of mRNA has been described Jarmolowski et al. 1994). These models were tested by kinetic competition experiments, which showed that injection of hnRN P A 1 into Xenopus oocyte nuclei specifically inhibited mRN A export, and this inhibition required the $M 9$ sequence. An M 9-containing fusion protein (N PC-M9) however, failed to inhibit mRN A export, demonstrating that the $\mathrm{M} 9 \mathrm{se}-$ quence, which is sufficient for export of N Pc-M 9, is nec- essary, but not sufficient, for mRN A export. Therefore, this result suggests that the ability of the hnRNP A1 protein to be exported out of the nucleus is not sufficient to promote mRN A export, and additional factors may be involved in this process (Izaurral de et al. 1997).

In the yeast $\mathrm{S}$. cerevisae, the nucleocytoplasmic shuttling protein $\mathrm{N} \mathrm{pl} 3 p$ and poly $(\mathrm{A})^{+}$RN A each require the presence of the other to be exported out of the nucleus (Lee et al. 1996). This study showed that temperaturesensitive mutations mapping to the RRM s of $\mathrm{N} \mathrm{pl3p}$ resulted in nuclear accumulation of poly $(A)^{+}$RN A. Interestingly, the two-RRM s of $\mathrm{N} \mathrm{pl3p}$ are very closely related to those of two-RRM SR proteins, such as SF2/ASF; the second RRM of $\mathrm{Npl} 3 p$ includes a unique heptapeptide signature present in two RRM SR proteins (Birney et al. 1993). The carboxyl terminus of $\mathrm{N} \mathrm{pl3p}$, however, contains only a limited number of RS di peptides and is more similar in overall composition to the glycine-rich carboxyl terminus of hnRNP A1 and related proteins. The domain and sequence similarity, together with the shared shuttling properties, suggest that yeast $\mathrm{N}$ pl 3p, metazoan hnRNP A1, and a subset of metazoan SR proteins, have related roles in mRNA transport or $\mathrm{mRNA}$ metabolism.

If SR proteins exit the nucleus bound to mRNA, they must be capable of associating di rectly or indirectly with exons. SR proteins associate with exonic sequences that function as splicing enhancers to promote spliceosome assembly in vitro (for review, see Fu 1995; Cáceres and Krainer 1997). In the case of the giant C. tentans Bal biani ring transcripts, as visualized by immunoelectron microscopy, the SR protein hrp45 was shown to bind a large exon throughout its length, remaining bound to the RN P particles in the nucleoplasm, to be released-on the nuclear side-only on translocation of the particles through the nuclear pore (Alzhanova-Ericsson et al. 1996). In mammalian cells, a subset of SR proteins and/ or SR-related proteins remain bound to the mature mRN A at the completion of an in vitro splicing reaction (Blencowe et al. 1994, 1995). Likewise, immunoprecipitation of labeled RN A from an in vitro splicing reaction with antibodies specific for SF2/ASF preferentially brings down the spliced mRNA, suggesting that SF2/ ASF remains bound to the exons (A. Hanamura, J.F. Cáceres, A. Mayeda, and A.R. Krainer, in prep.). In all likelihood, the dissociation of shuttling SR proteins from mature mRNA in vivo occurs in the cytoplasm, where these and other proteins are presumably exchanged for mRN P proteins, some of which are exclusivel y cytoplasmic. In contrast, nuclear restricted SR proteins, such as SC 35 and SRp40, must be removed from the RNP particles before nucleocytopl asmic transport. The dipteran protein hrp45 probably belongs to this class of SR proteins. It remains to be determined whether these proteins have nuclear retention signals, such as the one described for hnRNP C proteins (N akielny and Dreyfuss 1996).

In the present study, the use of chimeric constructs be tween a shuttling protein, SF2/ASF, and two nonshuttling proteins, SRp40 and SC 35, demonstrated that the 
RS domain of SF2/ASF is required for nucleocytoplasmic shuttling. We showed that the SF2/ASF RS domain conferred the ability to shuttle to a nonshuttling protein, SC 35, when it replaced the natural RS domain of this protein. Conversely, replacing the RS domain of SF2/ ASF by the RS domain of SRp40 converted a shuttling protein into one that remained confined to the nucleus (Fig. 3). N either RS domain from the shuttling SR proteins (SF2/ASF and SRp20), however, was sufficient to promote shuttling when fused to the nucleoplasmin reporter N Pc. This stands in contrast to the M 9 sequence of hnRN P Al, which is sufficient to activate the nucl ear export of the same nucleoplasmin reporter (Michael et al. 1995b). We conclude that the RS domain of SF2/ASF or SRp20 is necessary but not sufficient to promote the nuclear export of these shuttling SR proteins. Because it is most likely, as in the case of hnRNP proteins, that shuttling SR proteins exit the nucleus bound to RNA, additional specific signals required for shuttling may be present in these SR proteins or alternatively, the ability to shuttle may be conferred by binding to RNA. The fact that an RN A-binding impaired RRM mutant of SF2/ASF is not able to shuttle, strongly supports this latter possibility. Although our results so far strongly suggest that the RS domain of shuttling SR proteins acts as a nucl ear export signal, the RS domain swap experiments with different SR proteins could al so be explained by the presence of putative nuclear retention signals in the RS domains of nonshuttling proteins, such as SC 35 . The fact that the chimeric protein A1-RS, which comprises both RRM $S$ of hnRN P A 1 and the RS domain of SF2/ASF, is a shuttling protein, together with the fact that the export signal in hnRN P A 1 is separate from the RRM s, strongly suggests that the RS domain of SF2/ASF acts as a positive nuclear export signal, but also requires binding to RNA.

\section{Conservation and functions of RS domains}

The SR proteins have been extremely conserved as a family during eukaryotic evolution (Zahler et al. 1992; Birney et al. 1993). Individual SR proteins arose by ancient gene duplications, such that individual family members are more closely related to the corresponding members from different species than to other family members from the same species. The carboxy-terminal RS domains of SR proteins have low compositional compl exity and vary substantially in length and in the nature of the residues other than arginine and serine, such that the RS domains from different SR proteins have little more in common than the overall composition and the presence of many consecutive RS or SR dipeptides (Birney et al. 1993). N evertheless, the RS domains of individual SR proteins are as highly conserved as the rest of the protein. For example, the RS domains of human and mouse SF2/ASF, human and mouse SRp20, and human and chicken SC 35 are $98 \%-100 \%$ conserved at the amino acid level. The RS domain of human SF2/ASF is required for constitutive splicing in vitro (Cáceres and Krainer 1993; Zuo and M anley 1993) and for rescue of a gene disruption of the chicken homolog in a cell viability assay (Wang et al. 1996). Although the RS domain is thought to be involved in protein-protein interactions that serve as a bridge between the $5^{\prime}$ and $3^{\prime}$ splice sites across introns and across exons, and/or between exonic enhancers and the adjacent splice sites ( $\mathrm{Fu}$ and $\mathrm{M}$ aniatis 1992; Wu and M aniatis 1993; Chiara and Reed 1995), RS domain swaps between different human SR proteins showed that the identity of the RS domain is not important for the in vitro splicing activities of these proteins (Chandler et al. 1997). Mutational anal yses of SR protein function in vitro and in vivo showed further that the RS domain of these proteins is not required for alternative splice-site switching (Cáceres and Krainer 1993; Zuo and Manley 1993; Wang and Manley 1995; Cáceres et al. 1997). The very high degree of phylogenetic conservation of the SR proteins, and in particular of their RS domains, is suggestive of a specific function for each family member. We propose that the conservation of RS domain sequences reflects primarily the unique properties of individual SR proteins in subnuclear targeting (Cáceres et al. 1997) and nucl eocytoplasmic shuttling.

\section{Possible functions of shuttling SR proteins}

The fact that only some SR proteins shuttle between the nucleus and the cytoplasm, whereas others are exclusively nuclear, suggests that the different members of this family of proteins have unique functions, despite their close similarity in structure and biochemical properties. This finding al so rai ses the interesting possibility that, in addition to their multiple roles in general and regulated splicing in the nucleus, shuttling SR proteins may facilitate mRNA transport across the nuclear pore, or have cytoplasmic functions, such as translational regulation, mRNA stability, or mRNA localization. For instance, shuttling SR proteins may act as carriers to deliver proteins or RN A mol ecules to both cellular compartments. Another interesting possibility is that the transient passage of the shuttling SR proteins through the cytoplasm may allow their nuclear activities to be regulated by protein kinases or other cytoplasmic components, as proposed previously for the nucleolar proteins nucleolin and B23 (Borer et al. 1989).

Alternative splicing can be regulated through variations in the intracellular levels of antagonistic splicing factors (for review, see Cáceres and Krainer 1997). The regulation of nucleocytoplasmic shuttling of SR and hnRNP proteins may provide a novel mechanism for modulating the concentration ratio of SR and hnRN $P$ A/B proteins in the nucleus. In this regard, it has been shown recently that modulation of hnRN P A 1 shuttling is an early cellul ar response to genotoxic stress, and that this effect is mediated by the $\mathrm{MKK}_{3 / 6}-\mathrm{p} 38$ pathway $($. Lozano, J.F. Cáceres, A. M onjas, M.T. Diaz-M eco, A.R. Krainer, and J. M oscat, in prep.). The decrease of nuclear hnRN P A 1 resulting from its accumulation in the cytoplasm in response to genotoxic stress has the expected effect on alternative splicing, that is, a switch from distal to proximal 5' splice sites. Bell and coworkers found re- 
cently that expression of the Clk/Sty kinase, which can phosphorylate RS domains, results in changes in alternative splicing consistent with a decrease of SF2/ASF activity, that is, a switch from proximal to distal $5^{\prime}$ splice sites (Duncan et al . 1997). Our finding that expression of this kinase results in cytoplasmic accumulation of SF2/ASF, at the expense of the nuclear pool, suggests that the effect of RS domain phosphorylation on alternative splicing occurs by affecting the shuttling process, instead of, or in addition to, by down-regulating the intrinsic splicing activity of the protein. In the future it will be of interest to determine whether phosphorylation by Clk/Sty blocks nuclear reimport and/or nuclear export, as well as whether other kinases capable of phosphorylating RS domains have similar effects.

In addition to their pleiotropic properties on general and alternative splicing in the nucleus, at least some SR proteins are now implicated in additional functions in the cytoplasm. A particularly intriguing hypothesis is that shuttling SR proteins may have a role in nonsensemediated mRN A decay. In mammal ian cells this process is coupled to the presence of introns and is thought to be either a nuclear process or to involve communication between ribosomes and spliceosomes bound to a translocating mRNA (for review, see M aquat 1995). Because SR proteins, as well as hnRNP A/B proteins, appear to have a critical role in the selection of splice sites in the nucleus, they may serve to retain information about the position of introns that have already been spliced out (Carter et al. 1996), or otherwise to relate information between the nuclear and cytoplasmic portions of a translocating mRNA.

\section{Materials and methods}

\section{Epitope-tagged expression plasmids}

The epitope-tagged SR protein expression plasmids were previously described (Cáceres et al. 1997). Briefly, they were constructed by PCR amplification with specific primers and subcloning into the pCGTHCF $\mathrm{FL} \mathrm{T} 7$ expression vector (Wilson et al . 1995), in which transcription is driven by the CMV enhancer/ promoter (Tanaka and Herr 1990; Cáceres et al. 1994) and the coding sequence begins with an amino-terminal epitope tag, MASMTGGQQMG. This epitope tag corresponds to the first 11 residues of the bacteriophage $T 7$ gene 10 capsid protein and is recognized by the T7.tag monoclonal antibody (N ovagen). The SF2/ASF mutant in RRM 1, FF-DD, and the chimeric protein A1-RS were described previously (Cáceres and Krainer 1993; Mayeda et al. 1994, respectively) and were subcloned into the same expression vector. The nucleoplasmin fusion proteins were al so described previously (Cáceres et al. 1997). Briefly, the plasmid pCGT 7-N PC was constructed by amplifying a Xenopus nucleoplasmin CDN A with specific primers and cloning the resulting PCR product into the $\mathrm{Xbal}$ and $\mathrm{BamHI}$ sites of the $\mathrm{pC}$ $\mathrm{GTHCF}_{\mathrm{FL}} \mathrm{T} 7$ expression vector. This procedure results in the insertion of amino acids 2-149 of nucleoplasmin (known as the nucleoplasmin core domain, or N Pc), followed by an Xbal site and stop codon, carboxy-terminal to the T7 epitope. PCR fragments comprising residues 198-248 from the RS domain of SF2/ ASF or 88-164 from the RS domain of SRp20 were subcloned into pCGT 7-N Pc to generate N Pc- $\mathrm{RS}_{\mathrm{SF} 2}$ and N PC-RS $\mathrm{SRp20}_{\mathrm{S} \text {, re }}$ spectively.
To generate the SF2/SRp40 and SF2/SC 35 chimeras by swapping domains between the corresponding SR proteins, we took advantage of natural Sacl and Apal sites in the SF2/ASF CDN A, between RRM 1 and RRM 2, and between RRM 2 and the RS domain, respectively. PCR products comprising the indicated domains were amplified from cDNA clones using specific primer pairs. The resulting PCR products were assembled using the Sacl and Apal sites and subcloned into the pCGT 7 expression vector. The resulting chimeric proteins comprise the following residues. $\mathrm{I}_{\mathrm{SF} 2} \mathrm{II}_{\mathrm{SF} 2} \mathrm{RS}_{40}$ consists of residues 3-197 (RRM 1 and RRM 2) from SF2/ASF, followed by residues 184-271 (RS domain) from SRp40. $\mathrm{I}_{\mathrm{SF} 2} \mathrm{Il}_{40} \mathrm{RS}_{\mathrm{SF} 2}$ consists of residues 3-107 (RRM 1) and 196-248 (RS domain) from SF2/ASF, separated by residues 86-181 (RRM2) from SRp40. $\mathrm{I}_{\mathrm{SF} 2} \mathrm{Il}_{40} \mathrm{RS}_{40}$ comprises residues 3-107 (RRM 1) from SF2/ASF followed by residues 86271 (RRM 2 and RS domain) from SRp40. $\mathrm{I}_{40} \mathrm{II}_{\mathrm{SF} 2} \mathrm{RS}_{40}$ comprises residues 2-83 (RRM 1) and 184-271 (RS domain) from SRp40, separated by residues 107-197 (RRM 2) from SF2/ASF. I ${ }_{35} \mathrm{RS}_{\mathrm{SF} 2}$ comprises residues 2-114 (RRM) from SC35 followed by residues 197-248 (RS domain) from SF2/ASF. Plasmids encoding myc-epitope tagged Clk/Sty kinase, either a full-length active protein or a kinase-inactive mutant (M-Clk/Sty $\left.{ }^{\mathrm{K} 190 \mathrm{R}}\right)$, were a generous gift from Peter Duncan and John Bell (Duncan et al. 1995; Colwill et al. 1996).

\section{Cell culture and transfections}

HeLa cells were grown in Dulbecco's modified Eagle medium supplemented with $10 \%$ fetal calf serum and transfected with 1 $\mu \mathrm{g}$ of plasmid DNA per $60-\mathrm{mm}$ dish of $60 \%-75 \%$ confluent cells, in the presence of $20 \mu \mathrm{g}$ of lipofectin (GIBCO BRL) (Cáceres et al. 1994). For transient transfections involving interspecies heterokaryons, because of the need for higher transfection efficiency, transfection was carried out by el ectroporation using $10 \mu \mathrm{g}$ of plasmid DN A per $60-\mathrm{mm}$ dish of $90 \%$ confluent cells in the presence of $15 \mu \mathrm{g}$ of carrier DN A. For incubations of HeLa cells with transcriptional inhibitors, actinomycin $D$ was used at $5 \mu \mathrm{g} / \mathrm{ml}$, and DRB was used at $100 \mu \mathrm{m}$. In both cases, cycloheximide was added at $20 \mu \mathrm{g} / \mathrm{ml}$.

\section{Indirect immunofluorescence}

Cells were fixed for immunofluorescence assays at $24 \mathrm{hr}$ after transfection. The cells were washed with PBS and incubated with 3\% paraformal dehyde, $0.3 \%$ Triton (in PBS) for $5 \mathrm{~min}$ at room temperature, followed by incubation with $3 \%$ paraformaldehyde for $30 \mathrm{~min}$. The fixed cells were incubated for $1 \mathrm{hr}$ at room temperature with 1:500 anti-T7 monoclonal antibody (N ovagen Inc.), washed three times with PBS, and incubated for $1 \mathrm{hr}$ at room temperature with 1:500 fluorescein-conjugated goat anti-mouse IgG (Cappel Laboratories). Samples were observed on a Zeiss Axiovert 405M microscope and images acquired with a Photometrics N U200 cooled CCD camera using Oncor Image software. For local ization of endogenous SF2/ASF protein, a monoclonal antibody against SF2/ASF was used as culture supernatant at a 1:15 dilution (Cáceres et al. 1997). For localization of endogenous SC 35 protein, a monoclonal antibody against SC 35 was used as ascites at a 1:1000 dilution (Fu and $M$ aniatis 1990). For detection of the myc epitope, a rabbit polyclonal c-myc (A-14, Santa Cruz) antibody was used at a 1:500 dilution, and the secondary antibody was goat Texas Redconjugated anti-rabbit antibody (Cappel) at a 1:250 dilution.

The immunofluorescence figures in this report show representative data. Each experiment was reproduced in multiple independent transfections and the cells shown are representative of the large effects observed under each set of conditions. 


\section{Heterokaryon assays}

HeLa cells were transfected by electroporation and seeded on cover slips, followed by coincubation with an equal number of untransfected mouse NIH 3T 3 cells for $3 \mathrm{hr}$ in the presence of $50 \mu \mathrm{g} / \mathrm{ml}$ of cycloheximide. The concentration of cycloheximide was then increased to $100 \mu \mathrm{g} / \mathrm{ml}$ and the cells were incubated for an additional $30 \mathrm{~min}$ before fusion. Cell fusions were done as described (Piñol-Roma and Dreyfuss 1992), and the heterokaryons were incubated further for $2 \mathrm{hr}$ in media containing $100 \mu \mathrm{g} / \mathrm{ml}$ cycl oheximide before fixation. Immunofluorescence with the anti-T7 monoclonal antibody was performed as described above, except that Hoechst 33258 (Sigma) was included at $5 \mu \mathrm{g} / \mathrm{ml}$.

\section{Acknowledgments}

We thank Peter Duncan and John Bell (Ottawa) for the Clk/Sty expression vectors, and Serafín Piñol-Roma for hel pful discussions. We are grateful to Luca Cartegni, Tom Misteli, and Serafín Piñol-Roma for critical reading of the manuscript. G.R.S. was supported by the Wellcome Trust and the Arthritis and Rheumatism Council. J.F.C. and A.R.K. were supported by grant CA 13106 from the $\mathrm{N}$ ational Cancer Institute and by the Pew Charitable Trusts.

The publication costs of this article were defrayed in part by payment of page charges. This article must therefore be hereby marked "advertisement" in accordance with 18 USC section 1734 solely to indicate this fact.

\section{References}

Alzhanova-Ericsson, A.T., X. Sun, N. Visa, E. Kiseleva, T. Wurtz, and B. Daneholt. 1996. A protein of the SR family of splicing factors binds extensively to exonic Bal biani ring premRNA and accompanies the RNA from the gene to the nuclear pore. Genes \& Dev. 10: 2881-2893.

Birney, E., S. Kumar, and A.R. Krainer. 1993. Analysis of the RNA-recognition motif and RS and RGG domains: Conservation in metazoan pre-mRN A splicing factors. Nucleic Acids Res. 21: 5803-5816.

Blencowe, B.J., J.A. Nickerson, R. Issner, S. Penman, and P.A. Sharp. 1994. Association of nuclear antigens with exon-containing splicing complexes. J. Cell Biol. 127: 593-607.

Blencowe, B.J., R. Issner, J. Kim, P. McCaw, and P.A. Sharp. 1995. N ew proteins related to the Ser-Arg family of splicing factors. RNA 1: 852-865.

Borer, R.A., C.F. Lehner, H.M. Eppenberger, and E.A. Nigg. 1989. Major nucleolar proteins shuttle between nucleus and cytoplasm. Cell 56: 379-390.

Breeuwer, M. and D.S. Goldfarb. 1990. Facilitated nuclear transport of histone $\mathrm{H} 1$ and other small nucleophilic proteins. Cell 60: 999-1008.

Cáceres, J.F. and A.R. Krainer. 1993. Functional analysis of premRN A splicing factor SF2/ASF structural domains. EMBO J. 12: 4715-4726.

- - - 1997. Mammalian pre-mRNA splicing factors. In Eukaryotic mRNA processing (ed. A.R. Krainer), pp. 174-212. IRL Press, Oxford, U.K.

Cáceres, J.F., S. Stamm, D.M. Helfman, and A.R. Krainer. 1994. Regulation of alternative splicing in vivo by overexpression of antagonistic splicing factors. Science 265: 1706-1709.

Cáceres, J.F., T. Misteli, G.R. Screaton, D.L. Spector, and A.R. Krainer. 1997. Role of the modular domains of SR proteins in subnuclear localization and alternative splicing specificity. J. Cell Biol. 138: 225-238.

Carter, M.S., S. Li, and M.F. Wilkinson. 1996. A splicing-depen- dent regalatory mechanism that detects translation signals. EMBO J. 15: 5965-5975.

Chandler, S.D., A. Mayeda, J.M. Yeakley, A.R. Krainer, and X.D. Fu. 1997. RN A splicing specificity determined by the coordinated action of RNA recognition motifs in SR proteins. Proc. Natl. Acad. Sci. 94: 3596-3601.

Chiara, M.D. and R. Reed. 1995. A two-step mechanism for $5^{\prime}$ and 3' splice-site pairing. Nature 375: 510-513.

Colwill, K., T. Pawson, B. Andrews, J. Prasad, J.L. Manley, J.C. Bell, and P.I. Duncan. 1996. The Clk/Sty protein kinase phosphorylates SR splicing factors and regulates their intranuclear distribution. EMBO J. 15: 265-275.

Daneholt, B. 1997. A look at messenger RN P moving through the nuclear pore. Cell 88: 585-588.

Dingwall, C., S. Sharnick, and R.A. Laskey. 1982. A polypeptide domain that specifies migration of nucleoplasmin into the nucleus. Cell 30: 449-458.

Dingwall, C., S.M. Dilworth, S.J. Black, S.E. Kearsey, L.S. Cox, and R.A. Laskey. 1987. Nucleoplasmin CDNA reveals polyglutamic acid tracts and a cluster of sequences homologous to putative nuclear localization signals. EMBO J. 6: 69-74.

Dingwall, C., J. Robbins, S.M. Dilworth, B. Roberts, and W.D. Richardson. 1988. The nucleoplasmin nuclear location sequence is larger and more complex than that of SV40 Iarge T antigen. J. Cell Biol. 107: 841-849.

Dreyfuss, G., M .J. M atunis, S. Piñol-Roma, and C.G. Burd. 1993. hnRNP proteins and the biogenesis of mRNA. Annu. Rev. Biochem. 62: 289-321.

Duncan, P.I., B.W. Howell, R.M. Marius, S. Drmanic, E.M.J. Douville, and J.C. Bell. 1995. Alternative splicing of Sty, a nuclear dual specificity kinase. J. Biol. Chem. 270: 2152421531.

Duncan, P.I., D.F. Stojdl, R.M. Marius, and J.C. Bell. 1997. In vivo regulation of alternative pre-mRNA splicing by the Clk1 protein kinase. Mol. Cell. Biol. 17: 5996-6001.

Flach, J., M. Bossie, J. Vogel, A. Corbett, T. Jinks, D.A. Willins, and P.A. Silver. 1994. A yeast RN A-binding protein shuttles between the nucleus and the cytoplasm. Mol. Cell. Biol. 14: 8399-8407.

Fu, X.-D. 1995. The superfamily of arginine/serine-rich splicing factors. RNA 1: 663-680.

Fu, X.-D. and T. M aniatis. 1990. Factor required for mammalian spliceosome assembly is localized to discrete regions in the nucleus. Nature 343: 437-441.

-_- 1992. The 35-kDa mammalian splicing factor SC $35 \mathrm{me}$ diates specific interactions between $U 1$ and $U 2$ small nuclear ribonucleoprotein particles at the $3^{\prime}$ splice site. Proc. Natl. Acad. Sci. 89: 1725-1729.

Ge, H. and J.L. Manley. 1990. A protein factor, ASF, controls cell-specific alternative splicing of SV40 early pre-mRNA in vitro. Cell 62: 25-34.

Gui, J.F., W.S. Lane, and X.-D. Fu. 1994. A serine kinase regulates intracellular localization of splicing factors in the cell cycle. Nature 369: 678-682.

Guiochon-M antel, A., P. Lescop, S. Christin-Maitre, H. Loosfelt, M. Perrot-Applanat, and E. Milgrom. 1991. N ucleocytoplasmic shuttling of the progesterone receptor. EMBO J. 10: 3851-3859.

Huang, S. and D.L. Spector. 1996. Intron-dependent recruitment of pre-mRNA splicing factors to sites of transcription. J. Cell Biol. 133: 719-732.

Izaurral de, E., A. Jarmolowski, C. Beisel, I.W. Mattaj, G. Dreyfuss, and U. Fischer. 1997. A role for the M 9 transport signal of hnRN P A 1 in mRN A nuclear export. J. Cell Biol. 137: 2735.

Jarmolowski, A., W.C. Boelens, E. Izaurral de, and I.W. Mattaj. 
1994. N uclear export of different classes of RN A is mediated by specific factors. J. Cell Biol. 124: 627-635.

Jiménez-García, L.F. and D.L. Spector. 1993. In vivo evidence that transcription and splicing are coordinated by a recruiting mechanism. Cell 73: 47-59.

Kambach, C. and I.W. M attaj. 1992. Intracellular distribution of the $U 1 A$ protein depends on active transport and nuclear binding to U 1 snRNA. J. Cell Biol. 118: 11-21.

Krainer, A.R., G.C. Conway, and D. Kozak. 1990a. The essential pre-mRN A splicing factor SF2 influences 5 ' splice site selection by activating proximal sites. Cell 62: 35-42.

- - . 1990b. Purification and characterization of pre-mRNA splicing factor SF2 from HeLa cells. Genes \& Dev. 4: 11581171.

Laskey, R.A. and C. Dingwall. 1993. Nuclear shuttling: The default pathway for nuclear proteins. Cell 74: 585-586.

Lee, M.S., M. Henry, and P.A. Silver. 1996. A protein that shuttles between the nucleus and the cytoplasm is an important me diator of RNA export. Genes \& Dev. 10: 1233-1246.

Mandell, R.B. and C.M. Feldherr. 1990. Identification of two HSP70-related Xenopus oocyte proteins that are capable of recycling across the nuclear envelope. J. Cell Biol. 111: 1775-1783.

Manley, J.L. and R. Tacke. 1996. SR proteins and splicing control. Genes \& Dev. 10: 1569-1579.

Maquat, L.E. 1995. When cells stop making sense: Effects of nonsense codons on RNA metabolism in vertebrate cells. RNA 1: 453-465.

Mattaj, I.W. 1994. Splicing in space. Nature 372: 727-728.

Mayeda, A. and A.R. Krainer. 1992. Regulation of alternative pre-mRNA splicing by hnRNP A1 and splicing factor SF2. Cell 68: 365-375.

Mayeda, A., S.H. M unroe, J.F. Cáceres, and A.R. Krainer. 1994. Function of conserved domains of hnRNP Al and other hnRN P A/B proteins. EMBO J. 13: 5483-5495.

Mehlin, H. and B. Daneholt. 1993. The Bal biani ring particle: A model for the assembly and export of RNPs from the nucleus? Trends Cell Biol. 3: 443-447.

Meier, U.T. and G. Blobel. 1992. N opp140 shuttles on tracks between nucleolus and cytoplasm. Cell 70: 127-138.

Meyer, B.E. and M.H. Malim. 1994. The HIV-1 Rev transactivator protein shuttles between the nucleus and cytoplasm. Genes \& Dev. 8: 1538-1547.

Michael, W.M., H. Siomi, M. Choi, S. Piñol-Roma, S. N akielny, Q. Liu, and G. Dreyfuss. 1995a. Signal sequences that target nuclear import and nuclear export of pre-mRNA-binding proteins. Cold Spring Harb. Symp. Q uant. Biol. 60: 663-668.

Michael, W.M., M. Choi, and G. Dreyfuss. 1995b. A nuclear export signal in hnRNP A1: A signal-mediated, temperaturedependent nuclear protein export pathway. Cell 83: 415422.

Michael W.M., P.S. Eder, and G. Dreyfuss. 1997. The K nuclear shuttling domain: A novel signal for nuclear import and nuclear export in the hnRN P K protein. EMBO J. 16: 35873598.

Misteli, T. and D.L. Spector. 1996. Serine/threonine phosphatase 1 modulates the subnuclear distribution of pre-mRNA splicing factors. Mol. Biol. Cell 7: 1559-1572.

Misteli, T., J.F. Cáceres, and D.L. Spector. 1997. The dynamics of a pre-mRNA splicing factor in living cells. Nature 387: 523-527.

Moore, M.S. 1996. Protein translocation: N uclear export-out of the dark. Curr. Biol. 6: 137-140.

Nakielny, S. and G. Dreyfuss. 1996. The hnRNP C proteins contain a nuclear retention sequence that can override nuclear export signals. J. Cell Biol. 134: 1365-1373.
N igg, E.A. 1997. N ucleocytoplasmic transport: Signals, mechanisms and regulation. Nature 386: 779-787.

Piñol-Roma, S. and G. Dreyfuss. 1991. Transcription-dependent and transcription-independent nuclear transport of hnRNP proteins. Science 253: 312-314.

- - - 1992. Shuttling of pre-mRN A binding proteins between nucleus and cytoplasm. N ature 355: 730-732.

-_- 1993. hnRN P proteins: Localization and transport between the nucleus and the cytoplasm. Trends Cell Biol. 3: 151-155.

Pollard, V.W., W.M. Michael, S. N akiel ny, M.C. Siomi, F. Wang, and G. Dreyfuss. 1996. A novel receptor-mediated nuclear protein import pathway. Cell 86: 985-994.

Schmidt-Zachmann, M.S., C. Dargemont, L.C. Kühn, and E.A. $\mathrm{N}$ igg. 1993. N uclear export of proteins: The role of nuclear retention. Cell 74: 493-504.

Siomi, H. and G. Dreyfuss. 1995. A nuclear localization domain in the hnRNP A1 protein. J. Cell Biol. 129: 551-560.

Spector, D.L. 1993. Macromolecular domains within the cell nucleus. Annu. Rev. Cell Biol. 9: 265-315.

Spector, D.L., W.H. Schrier, and H. Busch. 1983. Immunoelectron microscopic local ization of snRN Ps. Biol. Cell 49: 1-10.

Tanaka, M. and W. Herr. 1990. Differential transcriptional activation by Oct-1 and Oct-2: Interdependent activation domains induce Oct-2 phosphorylation. Cell 60: 375-386.

Visa, N ., A.T. Alzhanova-Ericsson, X. Sun, E. Kileseva, B. Björkroth, T. Wurtz, and B. Daneholt. 1996a. A pre-mRN A-binding protein accompanies the RN A from the gene through the nuclear pores and into polysomes. Cell 84: 253-264.

Visa, N., E. Izaurral de, J. Ferreira, B. Daneholt, and I.W. Mattaj. 1996b. A nuclear cap-binding complex binds Balbiani ring pre-mRN A cotranscriptionally and accompanies the ribonucleoprotein particle during nuclear export. J. Cell Biol. 133: 5-14.

Wang, J. and J.L. Manley. 1995. Overexpression of the SR proteins ASF/SF2 and SC 35 influences alternative splicing in vivo in diverse ways. RNA 1: 335-346.

Wang, J., Y. Takagaki, and J.L. M anley. 1996. Targeted disruption of an essential vertebrate gene: ASF/SF2 is required for cell viability. Genes \& Dev. 10: 2588-2599.

Weighardt, F., G. Biamonti, and S. Riva. 1995. N ucleocytoplasmic distribution of human hnRNP proteins: a search for the targeting domains in hnRNP A1. J. Cell Sci. 108: 545-555.

Wilson, A.C., M.G. Peterson, and W. Herr. 1995. The HCF repeat is an unusual proteolytic cleavage signal. Genes \& Dev. 9: 2445-2458.

Wu, J.Y. and T. Maniatis. 1993. Specific interactions between proteins implicated in splice site selection and regulated alternative splicing. Cell 75: 1061-1070.

Yang, X., M.R. Bani, S.-J. Lu, S. Rowan, Y. Ben-David, and B. Chabot. 1994. The $A 1$ and $A 1^{B}$ proteins of heterogenous nuclear ribonucleoparticles modulate $5^{\prime}$ splice site selection in vivo. Proc. Natl. Acad. Sci. 91: 6924-6928.

Zahler, A.M., W.S. Lane, J.A. Stolk, and M.B. Roth. 1992. SR proteins: A conserved family of pre-mRNA splicing factors. Genes \& Dev. 6: 837-847.

Zahler, A.M., K.M. Neugebauer, W.S. Lane, and M.B. Roth. 1993. Distinct functions of SR proteins in alternative premRN A splicing. Science 260: 219-222.

Zandomeni, R., M.C. Zandomeni, D. Shugar, and R. Weinmann. 1986. Casein kinase type II is involved in the inhibition by 5,6-dichloro-1-beta-D-ribofuranosyl benzimidazole of specific RNA polymerase II transcription. J. Biol. Chem. 261: 3414-3419.

Zuo, P. and J.L. Manley. 1993. Functional domains of the human splicing factor ASF/SF2. EMBO J. 12: 4727-4737. 


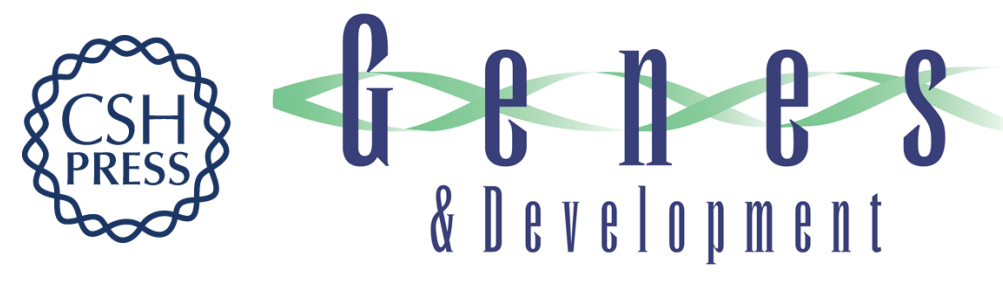

\section{A specific subset of SR proteins shuttles continuously between the nucleus and the cytoplasm}

Javier F. Cáceres, Gavin R. Screaton and Adrian R. Krainer

Genes Dev. 1998, 12:

Access the most recent version at doi:10.1101/gad.12.1.55

$\begin{array}{ll}\text { References } & \text { This article cites } 73 \text { articles, } 36 \text { of which can be accessed free at: } \\ \text { http://genesdev.cshlp.org/content/12/1/55.full.html\#ref-list-1 }\end{array}$

License

Email Alerting Receive free email alerts when new articles cite this article - sign up in the box at the top Service right corner of the article or click here.

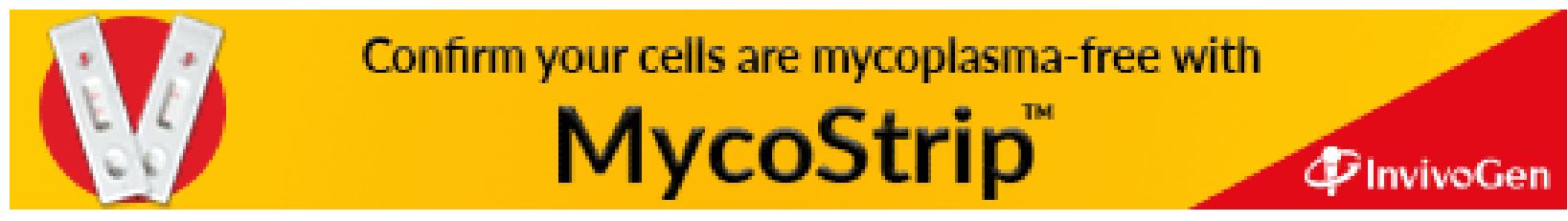

